\title{
Incidence of lung cancer by histological type among asbestos cement workers in Denmark
}

\author{
Edith Raffn, Elsebeth Lynge, Bente Korsgaard
}

\begin{abstract}
Objective-A significant twofold increased risk of lung cancer was found among 8000 men employed in the Danish asbestos cement industry between 1928 and 1984. The histological pattern of 104 lung cancer cases was studied with the aim of evaluating a relation between specific morphological types, duration of employment, and time since first employment.

Methods-Age, sex, and calendar time specific incidence of morphological subtypes of lung cancer (adenocarcinoma, squamous cell carcinoma, anaplastic carcinoma, and unspecified malignant tumour) for all Danish men were computed from 1943 to 1984 , from data routinely collected by the Danish Cancer Registry. Person-years of observation were counted from 15 years after the date of first employment until date of diagnosis of cancer, death, emigration, or the end of follow up on 31 December 1984. Expected numbers of cases were computed by applying person-years at risk to the appropriate incidence rates. Observed numbers were distributed accordingly and the relative risk calculated.
\end{abstract}

Results-The relative risk for adenocarcinoma was 3.31 (observed (O) 24, expected (E) $7 \cdot 26)$, for squamous cell carcinoma $1.67(0,37$, E, 22.12), for anaplastic carcinoma $1 \cdot 58(0,23$, $E, 14 \cdot 53)$, and for unspecified malignant tumour $1.57(0,18, E, 11.46)$. An increased risk by duration of employment and time since first employment was most pronounced for adenocarcinoma.

Conclusion-The link between adenocarcinoma and asbestos was confirmed in this, the first study of risk of lung cancer by histological

Danish Cancer Registry, Danish Cancer Society, Copenhagen, Denmark

E Raffn, E Lynge

Bedriftsundhedstjenesten, Dansk Eternit Fabrik, Aalborg, Denmark

B Korsgaard

Present address: Clinic of Occupational Medicine, State University Hospital, Copenhagen, Denmark E Raffn category based on incident cancer cases for a whole population during a 50 year period.

(British Journal of Industrial Medicine 1993;50:85-89)

Lung cancer is the most common cancer for men in Denmark with more than 2000 new cases occurring annually. ${ }^{1}$ Among asbestos workers lung cancer is the most frequent single cause of death. ${ }^{2}$ Selikoff et al found in their study on mortality among 18000 insulation workers in the United States that one out of five deaths was caused by lung cancer. ${ }^{3}$ The histopathological pattern of lung cancer among persons exposed to asbestos has been reported in several studies. $^{4-12}$ A preponderance of adenocarcinomas is present in some of these studies. ${ }^{4-8}$ The relative frequency of cell types seems, however, to depend on the source of pathological material, as shown by Whitwell et al. ${ }^{8}$ The question remains, therefore, whether there was, in fact, a higher proportion of adenocarcinomas or whether this high frequency was due to a bias in the material.

Thus we studied the incidence of lung cancer by histological type in a cohort of men previously employed in the asbestos cement industry in Denmark.

\section{Materials and methods}

In Denmark, asbestos cement products were manufactured by one factory only, Dansk Eternit in Aalborg. ${ }^{13}$ Production began in 1928 and accounted for $90 \%$ of the total amount of imported raw asbestos into Denmark.

Chrysotile asbestos was the only type of fibre used until 1946 when amosite was introduced. Small amounts of crocidolite were also used between 1952 and 1968.

Measurements of atmospheric asbestos particles carried out in 1948 and 1957 showed that the highest concentration of particles occurred during feeding the mill and the forming vessel. The Danish National Institute of Occupational Health has estimated that the concentration measured in fibres (f) per $\mathrm{ml}$ in 1948 varied between 50 and $800 \mathrm{f} / \mathrm{ml}$ and in 1957 between 10 and $100 \mathrm{f} / \mathrm{ml}$ ( $\mathrm{T}$ Schneider, personal communication). In $197341 \%$ of the exposure measurements were recorded as being above 2.0 $\mathrm{f} / \mathrm{ml}$. 
Information on all persons ever employed between 1928 and 1984 was extracted from the personnel files of the company. Over $99 \%$ of the employees were traced, giving a total of 7996 men and 584 women.

Information about death, causes of death, and cancer cases was extracted from municipality population registers, the Danish Cause of Death Register, and the Danish Cancer Register. The Danish Cancer Register contains information on all incident cancer cases diagnosed in Denmark since 1943. Between 1943 and 1977 cases of cancer were coded according to a modified version of ICD- $7^{14}$ in which a distinction was made between histologically verified subgroups of lung cancer. Since 1978 all cancer cases have been coded according to ICD- $0 .{ }^{15} 16$

Age, sex, and calendar year specific incidence rates by morphological subtype of lung cancer for all Danish males were computed. The following classification was used: unspecified malignant tumour, adenocarcinoma, squamous cell carcinoma, anaplastic carcinoma (including large cell and oat cell carcinomas), and other specified types.

Person-years were calculated from 15 years from the date of first employment until the date of cancer diagnosis, death, emigration, or the end of follow up on 31 December 1984. The expected number of cases was computed by applying person-years at risk to the appropriate incidence rates. Observed numbers were distributed accordingly, and the relative risks were estimated as the observed divided by the expected numbers. Two sided $95 \%$ confidence intervals $(95 \%$ CIs) for the relative risks were calculated using Byars approximation for the $\chi^{2}$ distribution. ${ }^{17}$

\section{Results}

Between 1943 and 1984 a total number of 162 cases of lung cancer were found among men employed at Dansk Eternit Fabrik during the period from 1928 to $1984 .{ }^{13}$ Table 1 shows the lung cancer cases by histological group. Squamous cell carcinoma was the most common cell type with 62 cases, then anaplastic carcinoma and adenocarcinoma with 38 and 32 cases respectively.

Three cases of lung cancer were excluded from further analysis because they belonged to a subgroup of 46 men with irregular working periods. Fifty five of the remaining lung cancer cases were diagnosed within 15 years of the date of first employment and were consequently also excluded from the analysis.

Table 2 presents the histological types of lung cancer seen among 104 men employed at the Dansk Eternit Fabrik after a latency of 15 years from the date of first employment. The relative risk was significantly increased for adenocarcinoma $(\mathrm{O} 24, \mathrm{O} /$ $\mathrm{E}=3.31 ; 95 \% \mathrm{CI} 2 \cdot 12-4.92)$, and for squamous cell carcinoma (O 37, O/E $=1 \cdot 67 ; 95 \% \mathrm{CI} 1 \cdot 18-2 \cdot 31)$. For anaplastic carcinoma $(\mathrm{O} / \mathrm{E}=1.58)$, and for
Table 1 Cases of lung cancer by histological type among men employed in the asbestos cement industry in Denmark 1928-84 and followed up from 1943 to 1984

\begin{tabular}{llc}
\hline$I C D-7$ & Histological type & No (\%) \\
\hline $162 \cdot 0,1$ & Unspecified malignant tumour & $25(15)$ \\
$162 \cdot 4$ & Adenocarcinoma & $32(20)$ \\
$162 \cdot 5$ & Squamous cell carcinoma & $62(38)$ \\
$162 \cdot 6$ & Anaplastic carcinoma & $38(24)$ \\
$162 \cdot 7$ & Other specified & $5(3)$ \\
$162 \cdot 0-7$ & All lung cancer cases & $162(100)$ \\
\hline
\end{tabular}

Table 2 Incidence of lung cancer by histological type among men in the asbestos cement industry in Denmark, with 15 years latency

\begin{tabular}{llrll}
\hline Histological type & $I C D-7$ & $O$ & $O / E$ & $95 \% C I$ \\
\hline Unspecified malignant tumour & $162 \cdot 0,1$ & 18 & $1 \cdot 57$ & $0.93-2 \cdot 48$ \\
Adenocarcinoma & $162 \cdot 4$ & 24 & 3.31 & $2 \cdot 12-4.92$ \\
Squamous cell carcinoma & 162.5 & 37 & $1 \cdot 67$ & $1 \cdot 18-2 \cdot 31$ \\
Anaplastic carcinoma & $162 \cdot 6$ & 23 & $1 \cdot 58$ & $1 \cdot 00-2 \cdot 38$ \\
Other specified & $162 \cdot 7$ & 2 & $1 \cdot 04$ & $0 \cdot 12-3 \cdot 76$ \\
All lung cancer cases & $162 \cdot 0-7$ & 104 & $1 \cdot 82$ & $1 \cdot 48-2 \cdot 20$ \\
\hline
\end{tabular}

histologically unspecified malignant tumour $(\mathrm{O} / \mathrm{E}=$ 1.57) the $\mathrm{O} / \mathrm{E}$ ratios were at the borderline of statistical significance.

Incidence of lung cancer was correlated with three durations of employment: less than one year, one to four years, and five years or more. Figure 1 and table 3 present the results. The relative risks were $2 \cdot 18,0 \cdot 96$, and 1.57 for squamous cell carcinoma and $1.56,0.98$, and 1.75 for anaplastic carcinoma in the respective three periods. The relative risk for adenocarcinomas was 2.32 among persons employed for less than one year. This risk increased to 3.60 for persons

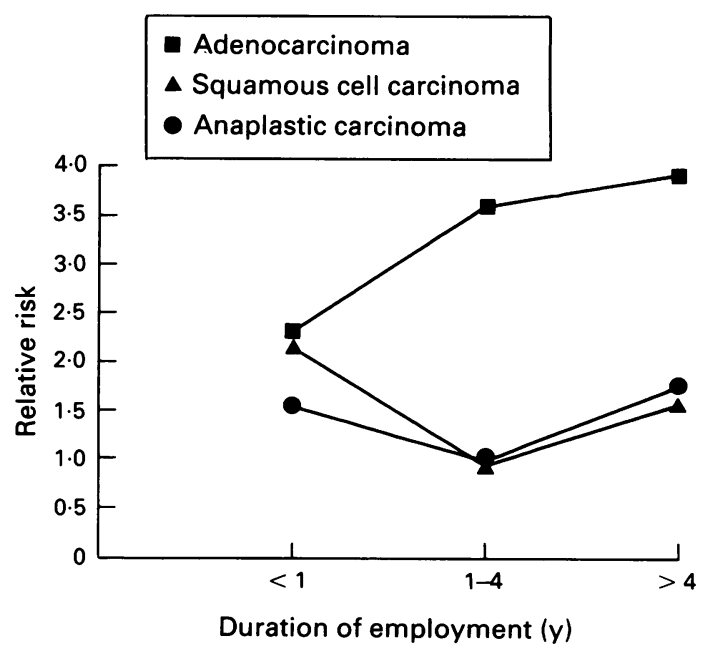

Figure 1 Incidence of lung cancer by histological type and duration of employment. 
Table 3 Incidence of lung cancer by histological type and duration of employment among men employed in the asbestos cement industry in Denmark, with 15 years latency

\begin{tabular}{|c|c|c|c|c|c|c|c|c|c|}
\hline \multirow[b]{3}{*}{ Histology } & \multicolumn{9}{|c|}{ Duration of employment (y) } \\
\hline & \multicolumn{3}{|l|}{$<1$} & \multicolumn{3}{|c|}{$1-4$} & \multicolumn{3}{|c|}{$\geqslant 5$} \\
\hline & $O$ & $E$ & $O / E(95 \% C I)$ & $O$ & $E$ & $O / E(95 \% C I)$ & $O$ & $E$ & $O / E(95 \% C I)$ \\
\hline $\begin{array}{l}\text { Unspecified malignant tumour } \\
\text { Adenocarcinoma } \\
\text { Squamous cell carcinoma } \\
\text { Anaplastic carcinoma } \\
\text { Other specified } \\
\text { All lung cancer }\end{array}$ & $\begin{array}{r}4 \\
16 \\
15 \\
7 \\
2 \\
34\end{array}$ & $\begin{array}{r}3 \cdot 61 \\
2 \cdot 58 \\
6 \cdot 87 \\
4 \cdot 49 \\
0 \cdot 39 \\
17 \cdot 94\end{array}$ & $\begin{array}{l}1 \cdot 11(0.30-2 \cdot 84) \\
2 \cdot 32(0.85-5 \cdot 06) \\
2 \cdot 18(1 \cdot 22-3.60) \\
1 \cdot 56(0.62-3 \cdot 21) \\
5 \cdot 08(0.58-18.52) \\
1.89(1.31-2 \cdot 65)\end{array}$ & $\begin{array}{r}2 \\
4 \\
3 \\
2 \\
0 \\
11\end{array}$ & $\begin{array}{l}1 \cdot 57 \\
1 \cdot 11 \\
3 \cdot 13 \\
2 \cdot 05 \\
0 \cdot 19 \\
8 \cdot 05\end{array}$ & $\begin{array}{l}1.27(0.14-4.60) \\
3.60(0.97-9 \cdot 23) \\
0.96(0 \cdot 19-2 \cdot 88) \\
0.98(0.11-3.52) \\
\frac{1}{1.37}(0.68-2.44)\end{array}$ & $\begin{array}{r}12 \\
14 \\
19 \\
14 \\
0 \\
59\end{array}$ & $\begin{array}{r}6 \cdot 28 \\
3 \cdot 57 \\
12 \cdot 12 \\
7 \cdot 99 \\
1 \cdot 34 \\
31 \cdot 31\end{array}$ & $\begin{array}{l}1.91(0.99-3.34) \\
3.92(2.14-6.58) \\
1.57(0.94-2.45) \\
1.75(0.96-2.94) \\
\frac{1}{1.88}(1.43-2.43)\end{array}$ \\
\hline
\end{tabular}

Table 4 Incidence of lung cancer by histological type and time since first exposure among men employed in the asbestos cement industry

\begin{tabular}{|c|c|c|c|c|c|c|c|c|c|}
\hline \multirow[b]{3}{*}{ Histology } & \multicolumn{9}{|c|}{ Time since first exposure $(y)$} \\
\hline & \multicolumn{3}{|c|}{$15-24$} & \multicolumn{3}{|c|}{$25-34$} & \multicolumn{3}{|c|}{$\geqslant 34$} \\
\hline & $O$ & $E$ & $O / E(95 \% C I)$ & $O$ & $E$ & $O / E(95 \% C I)$ & $O$ & $E$ & $O / E(95 \% C I)$ \\
\hline $\begin{array}{l}\text { Unspecified malignant tumour } \\
\text { Adenocarcinoma } \\
\text { Squamous cell carcinoma } \\
\text { Anaplastic carcinoma } \\
\text { Other specified } \\
\text { All lung cancer }\end{array}$ & $\begin{array}{r}6 \\
7 \\
18 \\
9 \\
2 \\
42\end{array}$ & $\begin{array}{r}5 \cdot 15 \\
3 \cdot 67 \\
10 \cdot 46 \\
7 \cdot 96 \\
0 \cdot 98 \\
27 \cdot 34\end{array}$ & $\begin{array}{l}1.17(0.43-2.54) \\
1.91(0.76-3.93) \\
1.72(1.02-2.72) \\
1.27(0.58-2.42) \\
2.04(0.23-7.37) \\
1.54(1.11-2.08)\end{array}$ & $\begin{array}{r}9 \\
10 \\
11 \\
11 \\
0 \\
41\end{array}$ & $\begin{array}{r}3 \cdot 44 \\
2 \cdot 12 \\
6 \cdot 88 \\
4 \cdot 48 \\
0 \cdot 65 \\
17 \cdot 59\end{array}$ & $\begin{array}{l}2 \cdot 62(1 \cdot 19-4 \cdot 97) \\
4 \cdot 72(2 \cdot 26-8 \cdot 68) \\
1 \cdot 60(0 \cdot 80-2 \cdot 86) \\
2 \cdot 46(1 \cdot 22-4 \cdot 39) \\
\frac{1}{2 \cdot 33}(1 \cdot 67-3 \cdot 16)\end{array}$ & $\begin{array}{r}3 \\
7 \\
8 \\
3 \\
0 \\
21\end{array}$ & $\begin{array}{r}2 \cdot 87 \\
1 \cdot 46 \\
4 \cdot 80 \\
2 \cdot 98 \\
0 \cdot 29 \\
12 \cdot 40\end{array}$ & $\begin{array}{l}1.05(0.21-3.05) \\
4.79(1.92-9.88) \\
1.67(0.72-3.28) \\
1.01(0.20-2.94) \\
\frac{1}{1.69}(1.05-2.59)\end{array}$ \\
\hline
\end{tabular}

employed from one to four years and to 3.92 for persons employed five years or more.

The relative risks for the histological types of lung cancer studied here were also correlated with time since first employment (table 4). The cohort was divided into three groups according to time since first exposure: these were 15 to 24 years, 25 to 34 years, and 35 or more. For anaplastic carcinoma the relative

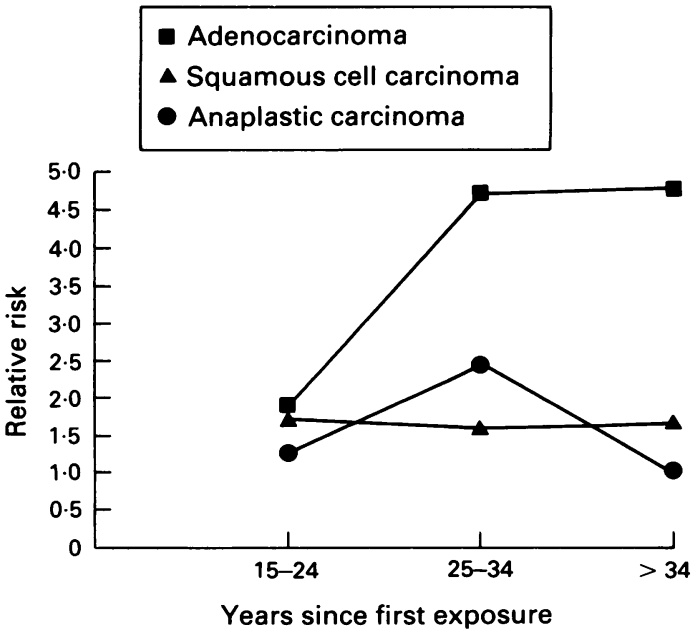

Figure 2 Incidence of lung cancer by histological type and time since first exposure. risks increased from 1.27 for the period 15 to 24 years since onset of exposure to 2.46 for the period 25 to 34 years since onset. The relative risk of anaplastic carcinoma decreased to 1.01 at 35 years or more after first employment. For adenocarcinomas the corresponding relative risks were $1.91,4.72$, and 4.79 respectively, for the periods 15 to 24,25 to 34 , and 35 or more years since first employment (fig 2).

\section{Discussion}

Our study, based on incidence data for cases of lung cancer diagnosed in Denmark since 1943, shows that the relative risk of adenocarcinoma of the lung among asbestos workers is two or more times higher than the

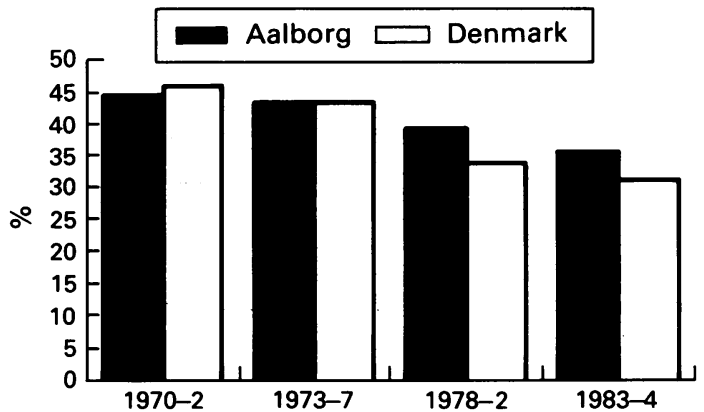

Figure 3 Frequency of necropsy among men in Denmark and in the city of Aalborg. 
relative risk of squamous cell carcinoma and anaplastic carcinoma of the lung. An increasing relative risk by duration of employment and time since first employment was found only for adenocarcinoma. Our results thus agree with the epidemiological studies of Hueper et al, Hourihane and McCaughey, Kannerstein and Churg, Warnock and Churg, and Whitwell et al, ${ }^{4-8}$ and with the experimental study of Davies et al. ${ }^{18}$

Whitwell et al have shown that histopathological diagnoses, based on bronchial biopsy specimens, give a higher frequency of squamous and small cell carcinoma and a corresponding lower frequency of adenocarcinoma than necropsy series. The reason for these differences is that the squamous and small cell carcinomas generally occur in the larger bronchi accessible to biopsy, whereas the adenocarcinomas are usually in peripheral locations. Necropsy series, on the other hand, give a higher proportion of adenocarcinomas that are more often placed peripherally. ${ }^{8}$ The reason could be that necropsies are more frequently made when the histological diagnosis is not known from biopsies, and these cases will by definition include a higher proportion of adenocarcinomas.

To evaluate a possible bias due to different sources of pathological material in Aalborg and in Denmark as a whole, we investigated whether the frequency of necropsy was higher in Aalborg than in the rest of the country. It was not (fig 3).

Smoking is assumed to be the predominant cause of lung cancer and accounts for $80-90 \%$ of all cases. ${ }^{10}$ Unfortunately, smoking habits have never been studied among the employees at Dansk Eternit A S. A cross sectional study on smoking habits among cement workers in Aalborg in 1973 showed that the prevalence of present and former smokers was $95 \%$, and $92 \%$ among men in Aalborg in general. ${ }^{20}$

The relation between squamous cell and small cell carcinomas of the lung and cigarette smoking is well established, ${ }^{21}$ but the relation between adenocarcinomas and cigarette smoking is still under discussion. ${ }^{22}$ Doll and Hill stated in their study of British doctors that there was no marked association between smoking and risk of adenocarcinoma of the lung,,$^{23}$ and Kreyberg made the assumption that adenocarcinomas have little or no causal relation with smoking. ${ }^{21}$ By contrast, Weiss and co-workers found that well differentiated squamous cell carcinoma, small cell carcinoma, and adenocarcinoma of the lung all displayed a dose response relation with smoking, ${ }^{24}$ as also shown by Lubin and Blot, although the risk for adenocarcinomas was at a reduced level. ${ }^{25}$

The interaction between tobacco smoking and exposure to asbestos as a cause of lung cancer is controversial and is often stated as multiplicative with reference to the study of Selikoff et al in $1968 .^{26}$ Steenland and Thun ${ }^{2 i}$ and Sarracci ${ }^{28}$ have reviewed all the asbestos studies with information about smoking habits to determine whether smoking modifies the effect of asbestos, and they concluded that the interaction varies between additivity and multiplicativity. None of the studies reviewed included data on tobacco smoking and exposure to asbestos in relation to histological type of lung cancer. The results in our study indicate that the relation between exposure to asbestos and the risk of adenocarcinoma of the lung is different from the relation between exposure to asbestos and the risk of squamous cell carcinoma and anaplastic carcinoma of the lung.

We thank Knud Juel, Danish Institute of Chemical Epidemiology, who provided data on frequency of necropsy in Denmark and Ebbe Villadsen and Lotte Lodberg Andersen for their help in data processing and secretarial assistance.

Requests for reprints to: Dr E Raffn, Clinic of Occupational Medicine, State University Hospital, Copenhagen, Denmark.

1 Frølund C, Krasnik M, Rosenstock S, Storm HH. Lungekræft i Danmark 1943-1986. Kræftstatistik nr. 26. [Lung cancer in Denmark 1943-1986: cancer statistics No 26]. Ugeskr Leeger 1990;10:1241-45.

2 Parkes WR. Occupational lung disorders. 2nd ed. London: Butterworths, 1982 .

3 Selikoff IJ, Hammond EC, Seidman H. Mortality experience of asbestos insulation workers in the United States and Canada. 1943. Ann NY Acad Sci 1979;330:91-116

4 Hueper WC. Occupational and environmentai cancer of the respiratorv tract. In: Recent results in cancer research. Vo! 3. Berlin: Springer, 1966;43

5 Hourihane DO'B, McCaughey WTE. Pathological aspects of asbestosis. Postgrad Med J 1966;42:613-22.

6 Kannerstein M, Churg J. Pathology of carcinoma of the lung associated with asbestos exposure. Cancer 1972;30:14-2;

7 Warnock ML, Churg AM. Association of asbestos in bronchogenic carcinoma in a population with low asbestos exposure. Cancer 1975;35:1236-42.

8 Whitwell F, Newhouse ML, Bennett DR. A study of the histological cell types of lung cancer in workers suffering from asbestosis in the United Kingdom. Br.l Ind Med 1974:31. 298-303.

9 Blot WJ, Harrington JM, Tolecio A, Hoover R, Heath CW Jr, Fraumeni JF Jr. Lung cancer after employment in shipyards during World War II. New Engl J Med 1978;299:620-4.

10 Finkelstein MM. Mortality among emplovees of an Ontario asbestos-cement factory. Am Rev Respir Dis 1984;129:754-61.

11 Auerbach O, Garfinkel L, Parks VR, et al. Histologic type of lung cancer and asbestos exposure. Cancer 1984;54:3017-21.

12 Churg A. Lung cancer cell type and asbestos exposure. Journai of the American Medical Association 1985;253:2984-5

13 Raffn E, Lynge E, Juel K, Korsgaard B. Cancer incidence and mortality among employees in the asbestos cement industry in Denmark. Br J Ind Med 1989;46:90-6.

14 Clemmesen J. Statistical studies in the aetiology of malignan neoplasms. I. Review and results. Acta Pathol Microbiol Scand 1977:Suppl.

15 World Health Organisation. ICD-O. International classification of oncology. Geneva: WHO, 1976.

16 Danish Cancer Registry. Cancer incidence in Denmark 1984 Copenhagen: Kræftens Bekæmpelse, Danish Cancer Society, 1987.

17 Breslow NE, Day NE. The standardized mortality ratio. In: Sen $\mathrm{PK}$, ed. Biostatistics in biomedical, public heaith and environmental sciences. North-Holland; Elsevier, 198 
18 Davies JMG, Beckett ST, Bolton RE, Collings PF, .Middleton AP. Mass and number of files in the pathogenesis of asbestos reiated lung disease in rats. $\mathrm{Br} J$ Cancer 1978;37:673-88.

19 Stanlev K, Hansen $\mathrm{HH}$. An international survey on attitudes in the control of lung cancer: A collaboration study between WHO and IASCC. Lung Cancer 1985;1:47-55.

20 Clemmesen J, Jensen SH. Cancer incidence among 5686 asbesioscement workers followed from 1943 through 1976. Ecotoxicol Environ Safety 1981;5:15-23.

21 Kreyberg L. Histological lung cancer types. A morphological and biological correlation. København: Munksgaard, 1962.

22 Ives JC. Buffler PA, Greenberg SO. Environmental associations and histopathologic patterns of carcinoma of the lung. The challenge and dilemma in epidemiologic studies. Am Rev Respir Dis 1983;128:195-209.

23 Doll R. Hill AB. Mortality in relation to smoking. Ten years' observation of British loctors. BMJ 1964;1:1399-410, 1460-7.

24 Weiss W, Boucot KR, Seidman H, Carnahan WI. Risk of lung cancer according to histologic type and cigarette dosage.
Journal of the American . Medical Association 1972;222: 799-801.

25 Lubin JH, Blot WJ. Assessment of Lung Cancer Risk Factors by Histologic Category. J Natl Cancer Inst 1984;73:383.

26 Selikoff IJ, Churg J, Hammond EC. Asbestos exposure and neoplasia. Journal of the American Medical Association 1964;188:142-6.

27 Steenland $\mathrm{K}$. Thun $\mathrm{M}$. Interaction between tobacco smoking and occupational exposures in the causation of lung cancer. $J$ Occup Med 1986;28:110-8.

28 Saracci $R$. The interactions of tobacco smoking and other agents in Cancer Ftiology. Epidemiol Rev 1987;9:175-93.

29 Raffn E, Lynge E, Juel K. Korsgaard B. Kraftrisiko og dodelighed blandt ansatta pa en asbestcementfabrik. cancer incidence and mortality among employees at an asbestos-cement factory in Denmark . København: Kræftens Bekæmpelse, Cancerregisteret, 1986.

Accepted 9 March 1992 